\title{
Meslek Yüksekokulu Öğrencilerinin Sigara Alışkanlıkları, İlgili Etmenler ve Sigara Konusundaki Bilgi Düzeyleri
}

\author{
Smoking Habits of Vocational School Students, Related Factors and \\ Their Knowledge Level on Smoking
}

\author{
Özgür Çelik, Figen Kadakal ${ }^{1}$, Ergin Sarar ${ }^{2}$, Sema Saraç $^{3}$, Ece Özdemir Babavatan ${ }^{4}$ \\ ${ }^{1}$ Kocaeli Sağlık ve Teknoloji Üniversitesi Avrupa Meslek Yüksekokulu, İstanbul, Türkiye \\ ${ }^{2}$ Biltes Koleji, İstanbul, Türkiye \\ ${ }^{3}$ Sağllk Bilimleri Üniversitesi Süreyyapaşa Göğüs Hastalıkları ve Göğüs Cerrahisi Eğitim ve Araştırma Hastanesi \\ ${ }^{4}$ İstanbul Aydın Üniversitesi Sağlık Hizmetleri Meslek Yüksekokulu, İstanbul, Türkiye
}

\author{
Yazışma Adresi / Correspondence: \\ Figen Kadakal \\ Kocaeli Sağlık ve Teknoloji Üniversitesi Avrupa Meslek Yüksekokulu, İstanbul, Türkiye \\ T: +90532727 $7077 \quad$ E-mail : figenkadakal@yahoo.com \\ Geliş Tarihi / Received : 22.02.2021 Kabul Tarihi / Accepte: 22.08.2021 \\ Orcid : \\ Özgür Çelik https://orcid.org/0000-0002-5660-2831 \\ Figen Kadakal https://orcid.org/0000-0003-0762-5671 \\ Ergin Sarar https://orcid.org/0000-0002-4695-661X \\ Sema Saraç https://orcid.org/0000-0002-1629-7035 \\ Ece Özdemir Babavatan https://orcid.org/0000-0002-2583-2896 \\ ( Sakarya Tip Dergisi / Sakarya Med J 2021, 11(3):542-553) DOI: 10.31832/smj.884821
}

\footnotetext{
$\ddot{O} z$

Amaç Sigara kullanımı, dünya çapında mortalite ve morbiditenin önlenmesinde en önemli değiștirilebilir risk faktörüdür. Çalıșmamızda, bir meslek yüksekokulunda değişik sağlık programlarında öğrenim gören öğrencilerin sigara konusundaki durumlarını, bilgilerini ve farkındalıklarını araştırmak amaçlandı.

Gereç ve Gerekli yasal ve etik izinler sonrasında, kesitsel tanımlayıcı tipte yapılan bu çalıșma, İstanbul'daki bir meslek yüksekokulunda çeșitli sağlık ve eğitim programlarında

Yöntemler okumakta olan toplam 173 öğrencinin katılımıyla gerçekleşmiştir. Araştırmaya katılan öğrencilere 7'si demografik verileri içeren toplam 43 soruluk bir değerlendirme formu uygulanmıștır. Verilerin analizi için tanımlayıcı istatistiksel metotlar ve Ki-kare testi kullanılmıștır. Anlamlılık düzeyi, $p<0.05$ üzerinden değerlendirilmiștir.

Bulgular En yüksek oranda sigara içen yaş grubunun, 20-21 yaş grubu (\%54.9) olduğu belirlenmiștir. Öğrencilerin cinsiyet değișkenine bağlı dağılımlarına göre \%39.9’unun kadın ve \%60.1'inin ise erkek olduğu belirlenmiștir. Öğrencilerin \%6.35'inin "bir kez deneyip sevmedikleri", \% 45.65 'inin "sigara içmediği”" ve \%48'inin ise "halen sigara içtiği”" belirlenmiștir. Sigara içen öğrencilerin \%38.6’sı sigarayı bırakmak istediğini, \%61.4’üi ise istemediğini söylemiștir. Öğrencilerin sigara içme durumlarına göre, baba sigara içme durumu karşılaştırıldığında, gruplar arasında anlamlı farkllık meydana geldiği görülmüștür (p:0.021). Sigara içen öğrencilerin, babalarının da sigara içme oranının daha yüksek olduğu saptanmıștır.

Sonuç Çalıșmamızda elde edilen sonuçlar değerlendirildiğginde, meslek yüksekokulunda öğrenim gören öğrencilerin sigara içme alıskanlıklarının ve sigara tüketme oranlarının benzer çalışmalara göre daha yüksek olduğu belirlenmiştir. Sigara alışkanlığı olanların alkol ve nargile gibi alışkanlıklarının da olduğu, baba sigara içme durumunun, sigara bağımlılı̆ını etkilediği görülmüștür. Sağlık ve eğitim alanında çalışmaya aday olan öğrencilerin, sigaraya başlamasını önlemek ve sigara içenlerin de bırakmalarını desteklemek için, okullardaki eğitim programlarında, bu konunun daha fazla ele alınması gerektiği düşünüyoruz.

Anahtar Sigara; bağımlılık; alışkanlık; meslek yüksekokulu

Kelimeler

Abstract

Objective Smoking is the most important modifiable risk factor in preventing mortality and morbidity worldwide. In our study, it was aimed to investigate the status, knowledge and awareness of students studying in a vocational school.

Materials After the necessary legal and ethical permissions, this cross-sectional descriptive study was carried out with the participation of 173 students who studying in a vocational school in Istanbul. and Methods An evaluation form that have 43 questions, 7 of which includes demographic datas, was applied to the students participating in the study. Descriptive statistical methods and Chi-square test were used for data analysis. The level of significance was evaluated over $p<0.05$.

Resulrs It was determined that the age group with the highest rate of smoking was the 20-21 (54.9\%).According to the distribution of the students depending on the gender variable, it was determined that $39.9 \%$ of them were female and $60.1 \%$ were male. It was determined that $6.35 \%$ of the students " tried it once or not ", $45.65 \%$ "did not smoke "and $48 \%$ " still smoked ". It was found that the smoking rate of the fathers of the smokers was also higher.

Conclusion In our study, it was determined that the smoking habits and smoking rates of the students studying at vocational high school were higher than similar studies. We think that this issue should be handled more in educational programs in schools, to prevent starting to smoke and support smokers to quit, who are candidates to work in the field of health and education.

Keywords Smoking; addiction; habit; vocational school
} 


\section{GíRiș}

Tütün ürünlerinden biri olan sigara, bulaşıcı olmayan hastalıkların, sakatlıkların ve önlenebilir ölümlerin en önemli nedenidir. Sigara, içerdiği nikotin nedeniyle bağımlılık yapıcıdır, ayrıca çeşitli zararlı maddeleri içerdiği için, içenlerde veya pasif içicilerde, birçok sağlık sorununa yol açmaktadır. ${ }^{1}$ Sigara içenlerin yarısından çoğunun, sigaraya bağlı bir nedenle hayatını kaybettiği belirlenmiştir. Sigara içen kişilerde, sigaraya bağlı olarak en sık görülen ölüm nedenleri arasında çeşitli kanserler, inme (felç), akciğer ve kalp hastalıkları gelmektedir. ${ }^{2}$ Sigara bağımlılığı, Dünya Sağlık Örgütü tarafından "küresel salgın alarmı" verilen nadir sağlık sorunlarından birisidir. ${ }^{3}$

Dünya Sağlık Örgütü (DSÖ) Küresel Tütün Raporu’nda; dünyada 1,3 milyar sigara içicisi mevcut olup, her yıl sigaraya bağlı sebeplerden 6 milyon insan öldüğü bildirilmiştir. Tütün kullanımının, mevcut eğilim devam ederse, 2030 yılına kadar, her yıl dünya çapında, \%80'i düşük ve orta gelirli ülkelerde olmak üzere, 8 milyondan fazla insanın ölümüne neden olacağı bildirilmektedir. ${ }^{4}$

Türkiye İstatistik Kurumu’nun (TÜİK) 2016 verilerine göre, Türkiye’de 15 yaş üzeri nüfusun \%26.5’i her gün bir tütün ürünü kullanmaktadır. 18 yaş altındaki çocukların 250 bini sigara içmektedir. ${ }^{5}$

2017 yılında ülkemizde yapılan Küresel Gençlik Tütün Araştırması'nda 13-15 yaş arasındaki yaklaşık 122 bin öğrencinin \%7.7'sinin halen sigara içtiği saptanmıştır. ${ }^{6}$

Gençler, yetişkin gibi görünmek, bir gruba ait olmak, kabul görmek, sosyal ortamlarda kolay etkileşim kurmak ve eğlenmek için madde kullanmaya başlayabilir., ${ }^{2,3}$ Bağımlılık sorunlarından en sık görülenlerden birisi olan sigara kullanımına genellikle ergenlik döneminde başlanır. Bu dönemde sigaraya başlayanların yarısı, 15-20 yıl süreyle sigara içebilir ve kişinin sigaraya bağımlı olması birkaç ay ile 3 yll içerisinde gerçekleşebilmektedir. ${ }^{7}$
A Report of Surgeon General (Genel Cerrah Raporu) 2014 'te belirtildiği gibi, eğer gençler sigara kullanmaya 26 yaşına kadar başlamazlarsa, genellikle artık hiç sigara içmezler. ${ }^{8}$ Sigara içicisi erişkinlerin \%80'i, sigara içmeye 18 yaş öncesinde başlamıştır. Artan bilimsel kanıtlar, 12-18 yaş arası ergenlik devresinde beyinde yapısal ve kimyasal değişiklikler oluştuğunu ortaya koymuştur. Ergen beyni, nikotine erişkinden farklı cevap vermekte ve yaşam boyu sürecek bağımlılık oluşmaktadır. ${ }^{9}$

Özellikle tütün kullanımına başlama konusunda risk almaya eğilimli olan gençlerin tütün kullanmamasına yönelik çabaların artması tütünsüz toplumlar için gereklidir. Gençlere çok çeşitli yollarla ulaşabilmek olanaklıdır. Bu gruba yönelik etkili ve sürekli çalışmaların yapılabilmesi için gençlerin bir arada yaşamlarını sürdürdüğü eğitim kurumları arasında olan üniversitelere öncelik verilmelidir.

Üniversitelerde okuyan gençlerin, tütün endüstrisinin de hedef grubu olmasından dolayı bu gruba yönelik müdahale programlarının önemi artmaktadır. ${ }^{10}$

Özellikle sağlık alanında eğitim gören ve sağlık alanında çalışma adayı olan öğrencilerin, kendi sağlıkları ve gelecekte topluma iyi bir rol model olmaları için sigara ve birçok bağımlılık konusunda eğitilmeleri gereklidir. Okullarda eğitim programlarının bu bilinçle oluşturulması büyük önem taşımaktadır. Ülkemizde bu konudaki eğitimin hala yeterli düzeyde olmaması nedeniyle, biz de tekrar bu konuya dikkat çekmek ve en azından kurumumuzda bu bilinci ve farkındalığı oluşturabilmek amacıyla İstanbul'daki bir meslek yüksekokulunda, çeşitli sağlık programlarında eğitim gören öğrencilerin sigara içme durumlarını, sigaranın zararları hakkındaki bilgi düzeyleri ve farkındalıkları$\mathrm{n} ı$ araştırmayı amaçladık.

\section{GEREÇ ve YÖNTEMLER}

Kesitsel tipte tanımlayıcı bir çalışma olarak planlanan bu araştırmanın evreni çalışmış olduğumuz meslek yüksekokulunda 2019 bahar döneminde öğrenim gören 1 . 
ve 2. sınıf öğrencilerinden oluşturuldu. Çalışmada örneklem seçilmemiştir ve tüm öğrencilere ulaşmak hedeflenmiştir. Çalışmaya başlamadan önce etik kurul onayı Sağlık Bilimleri Üniversitesi Süreyyapaşa Göğüs Hastalıkları ve Göğüs Cerrahisi Girişimsel Olmayan Klinik Araştırmalar Etik Kurulu tarafından alınmış olup (116.2017.112 numaralı, 28.11.2019) Helsinki bildirisine uygundur.

Veri toplama aşamasında öğrencilere araştırmanın amacı ve kapsamı anlatılmış, araştırmaya katılmayı kabul ettiklerine dair sözlü onamları alınmıştır. Çalışma sırasında sınıfta bulunmayan, çalışmamıza katılmayı kabul etmeyen ve değerlendirme formunu tam olarak doldurmayan öğrenciler çalışmaya dâhil edilmemiştir. Formları eksiksiz tamamlayan, 173 öğrenci çalışmaya dâhil edilmiştir. Araştırmaya katılan öğrencilere, 6'sı sigara hakkındaki bilgi düzeyini ölçen, 7'si demografik verileri içeren, 30'u sigara kullanımı ile ilişkili soruları kapsayan toplam 43 soruluk bir değerlendirme formu uygulanmıştır.

Veriler, tanımlayıcı istatistiksel metotlar ve Ki-kare testi kullanılarak analiz edilmiştir. Anlamlılık p <0.05 düzeyinde değerlendirilmiştir.

\section{BULGULAR}

Öğrencilerin yaş değişkenine göre dağılımları incelendiğinde \%1.2'sinin 18 yaşından küçük, \%12.7'sinin 18-19 yaş, \%54.9'unun 20-21 yaş, \%31.2'sinin 21 yaşından büyük oldukları, cinsiyet değişkenlerine göre dağılımları ise \%39.9'unun kadın ve \%60.1'inin erkek olduğu görülmektedir (Tablo 1).

Öğrencilerin eğitim durumu değişkenine göre dağılımları incelendiğinde \%23.1'nin sağlık lisesi ve \%76.9'unun ise diğer liselerden mezun oldukları görülmektedir. Öğrencilerin okudukları programlara göre dağılımları incelendiğinde en fazla oranın \%31.8'inin (n:55) ilk ve acil yardım, ardından da \%27.7’sinin (n:48) çocuk gelişimi bölümlerinde öğrenim gördükleri belirlenmiştir.
“Öğrencilerin halen sigara içiyor musunuz?” sorusuna verdikleri yanıtlar incelendiğinde \%6.35 oranında "1 kez denedim sevmedim", \%45.65 oranında "Hayır" ve \%48 oranında ise "Evet" yanıtını verdikleri görülmektedir. Sigara içen öğrencilerin \%33.73’ünün (n:28) kadın, \%66.27’sının (n:55) ise erkek olduğu saptanmıştır. Öğrencilerin sigara içme sıklığ ise her gün sigara içtiği ifade edilmiştir (Tablo 2).

Tablo 1. Yaş, cinsiyet, medeni hal ve çalışma durumlarına göre orantisi

\begin{tabular}{|l|c|c|}
\hline Yaş & Frekans (N) & Yüzde (\%) \\
\hline 18 'den küçük & 2 & 1.2 \\
\hline $18-19$ & 22 & 12.7 \\
\hline $20-21$ & 54 & 54.9 \\
\hline 21 'den büyük & & 31.2 \\
\hline Cinsiyet & 69 & \\
\hline Kadın & 104 & 39.9 \\
\hline Erkek & & 60.1 \\
\hline Medeni hal & 3 & 1.7 \\
\hline Evli & 170 & 98.3 \\
\hline Bekâr & & \\
\hline Çalışma durumu & 161 & 93.1 \\
\hline Çalışmıyor & 12 & 100.0 \\
\hline Çalışıyor & 173 & \\
\hline Toplam & & \\
\hline
\end{tabular}

Tablo 2. Sigara içme durumları ve sigara içme sıklığına göre orantisı

\begin{tabular}{|l|c|c|}
\hline Sigara içme durumu & Frekans (N) & Yüzde (\%) \\
\hline Evet & 83 & 48.0 \\
\hline Hayır & 79 & 45.65 \\
\hline Bir kez denedim sevmedim & 11 & 6.35 \\
\hline Toplam & 173 & 100.0 \\
\hline Sigara içme sıklığ1 & & \\
\hline Her gün & 61 & 73.5 \\
\hline Ara sıra & 22 & 26.5 \\
\hline Toplam & 83 & 100.0 \\
\hline
\end{tabular}


Öğrencilerin sigaraya başlama yaşının en fazla \%25.3 oranıyla (n:21) 18 yaş olduğu belirlenmiştir.

Öğrencilerin sigaraya başlama nedenleri arasında en sık görüleni \%33.68 (n:32) oranında diğer nedenler (öylesine, bilinçli olarak, duygusal nedenler), \%26.32 (n:25) oranında stres ve sıkıntı olduğu tespit edilmiştir.

Öğrencilerin sigara içmeyi sürdürme nedenleri incelendiğinde \%4.8’i (n:4) okul-ders stresine iyi geldiğini, \%13.3’ü (n:11) bağımlılık alışkanlık, \%33.7’si (n:28) diğer nedenler, \%48.2'si (n:40) ise zevk-keyif verici olduğunu belirtmişlerdir.

Sigara içen öğrencilerin günlük olarak tükettikleri sigara miktarları incelendiğinde $\% 56.6$ 'sının 10 ve altı, \%34.9'unun 11-20, \%4.8'inin 21-30, \%3.6'sinin ise 31 ve üzeri adet sigara tükettikleri görülmüştür. Sigara içme süreleri açısından sigara içen öğrencilerin \%33.3'ünün 1 yıl, \%24.1'inin 2 yıl, \%10.3'ünün da 3 y1l, \%8'inin 4 yıl, \%5.7'sinin 5 yıl, \%6.9'unun 6 yıl, \%2.3'ünün 7 ve 8 yıl, \%3.4'ünün 10 ve 12 yıl sigara içtikleri belirlenmiştir. Öğrencilerin içtikleri sigara tipi incelendiğinde ise \%2.3’ünün diğer türlerde (puro, pipo), \%31'inin filtresiz, \%66.7’sinin filtreli sigara içtiği belirlenmiştir.

Sigara bağımlılığı olan öğrencilerin, sigaranın yanında başka alışkanlıklarının olup olmadığı sorusuna verdikleri yanıtlar incelendiğinde \%3.61'inin başka alışkanlıklarının olmadığı, \%13.25'inin diğer bağımlılıklar (uyuşturucu madde), \%27.71'inin nargile, \%55.42'sinin ise alkol yanıtını verdikleri görülmüştür. Sigara içmeyen öğrencilerin, alkol, nargile vb. alışkanlıklarının da olmadığı belirlenmiştir.

Sigara içen öğrencilerin, sigara ile ilgili olarak yaşadıkları sağlık sorunu olup olmadığı sorusuna verdikleri yanıtlar incelendiğinde \%24.1'inin (n:20) "Evet” ve \%75.9'unun (n:63) ise "Hayır" yanıtını verdikleri tespit edilmiştir. Öğrencilerin sigarayla ilişkili olduğunu düşündükle- ri sağlık sorunları hakkındaki ifadeleri incelendiğinde \%12.05’inin (n:10) nefes darlığı, \%31.32'sinin (n:26) öksürük, \%56.63’ünün (n:47) ise balgam olduğu görülmektedir. Tüm öğrencilerin sigara ile ilgili olarak duydukları ve etkilendikleri sloganlar incelendiğinde, birinci sırada "Sigara içenler genç yaşta ölür" (\%34.1), ikinci sırada ise "Sigarayı bırakmak ölümcül kalp ve akciğer hastalıklarını azaltır" (\%32.4) sloganı gelmektedir (Tablo 3).

\begin{tabular}{|l|c|c|}
\hline \multicolumn{3}{|l|}{ Tablo 3. Sigara karşıtı sloganlara göre etkilenme orantısı } \\
\hline $\begin{array}{l}\text { Sigara karşıtlığı ile ilgili slo- } \\
\text { ganlar }\end{array}$ & Frekans (N) & Yüzde (\%) \\
\hline Sigara içenler genç yaşta ölür & 59 & 34.1 \\
\hline $\begin{array}{l}\text { Sigara içmek kan akışını yavaşlatır } \\
\text { ve cinsel iktidarsızlığa neden olur }\end{array}$ & 16 & 9.2 \\
\hline $\begin{array}{l}\text { Sigara içmek cildin erken yaşlan- } \\
\text { masına neden olur }\end{array}$ & 42 & 24.3 \\
\hline $\begin{array}{l}\text { Sigarayı bırakmak ölümcül kalp } \\
\text { ve akciğer hastalıklarını azaltır }\end{array}$ & 56 & 32.4 \\
\hline Toplam & 173 & 100.0 \\
\hline
\end{tabular}

Öğrencilerin “Sigarayı bırakmak istiyor musunuz?” sorusuna verdikleri yanttlar incelendiğinde \%38.6's1 "Evet” ve \%61.4'ü ise "Hayır” yanıtını vermiştir.

Sigara içen öğrencilerin sigarayı bırakmak isteme nedeniniz nedir?" sorusuna verdikleri cevaplarda en yüksek oran ile birinci sirada "Gelecekte hastalanma korkusu” (\%44.2), ikinci sırada ise "Ekonomik nedenler" (\%30.8) olduğu belirlenmiştir.

Öğrencilerin sigara içtikleri için pişmanlık duyma durumları incelendiğinde, en yüksek oran ile "Bazen pişmanlık duyuyorum" (\%63.8), \%22.3 oranıyla "Pişmanlık duymuyorum” yanıtını verdikleri görülmektedir.

Öğrencilerin "Sigara ağız kokusuna yol açar mı?” sorusuna verdikleri yanıtlar incelendiğinde \%6.9'unun (n:12) "Hayır", \%93.1'inin (n:161) ise "Evet", "Sigara diş etinde ve dişlerde hastalık yapar mı?” sorusuna \%2.3’ünün (n:4) "Yapmaz", \%97.7'sinin (n:169) ise "Yapar" yanitını verdikleri belirlenmiştir. 
Öğrencilerin "Sigara gırtlak kanserine yol açar mı?” sorusuna verdikleri yanıtlar incelendiğinde \%5.2'sinin (n:9) "Hayır", \%94.8'inin (n:164) ise "Evet", "Sigara akciğer kanserine sebep olur mu?" sorusuna \%2.3’ünün (n:4) "Hayır”, \%97.7’sinin (n:169) ise "Evet" yanıtını verdiği görülmektedir.

Öğrencilerin “Sigara kısırlık nedeni olabilir mi?” sorusuna verdikleri yanıtlar incelendiğinde \%8.7'si (n:15) "Hayır", \%91.3'ü (n:158) ise "Evet”, "Sigara erken doğum ve düşük nedeni olabilir mi?" sorusuna \%4.6'sı (n:8) "Hayır”, \%95.4'ü (n:165) ise "Evet” yanıtını vermişlerdir.

Öğrencilerin “Nasıl yaşıyorsunuz?” sorusuna verdikleri yanıtlar incelendiğinde \%4.1'inin (n:7) Evde tek başına”, \%9.2'sinin (n:16) "Yurtta" \%20.8'inin (n:36) "Evde arkadaşlarıyla", \%65.9'unun (n:114) ise "Evde ailesiyle" yaşadı̆̆ı görülmektedir.

Öğrencilerin "Yaşadığınız yerde sizden başka sigara içen var mi?" sorusuna verdikleri yanıtlar incelendiğinde \%30.1'inin "Hayır", \%69.9'unun ise "Evet" yanıtını verdiği saptanmıştır.

Öğrencilerin, anne sigara içme durumuna göre dağılımları incelendiğinde \%3.5'inin (n:6) "Sigara içmeyi bıraktı", \%31.8'inin (n:55) "Evet" ve \%64.7'sinin ise (n:112) "Hayır" yanıtını verdiği tespit edilmiştir.

Öğrencilerin, baba sigara içme durumuna göre dağılımları incelendiğinde \%9.2'si (n:16) "Sigara içmeyi bıraktı", \%32.9’u (n:57) "Hayır" ve \%57.8'i ise (n:100) "Evet” yanıtını vermişlerdir.

Öğrencilerin, yaşadıkları ortamda sigara içilme durumları sorulduğunda \%26.6’sının (n:46) "Hayır”, \%73.4'ünün ise (n:127) "Evet” yanıtını verdiği saptanmıştır.

Sigara içen ve içmeyen öğrenciler cinsiyetlerine göre değerlendirildiğinde, sigara içen öğrencilerin cinsiyetleri arasında anlamlı farklılık meydana geldiği, erkek öğrencilerin daha yüksek oranda sigara içtikleri (p:0.003) görülmektedir.

Öğrencilerin sigara içme durumlarına göre, eğitim durumları Ki-kare testi ile karşılaştırıldığında gruplar arasında anlamlı farklılık meydana geldiği (p:0.945) görülmektedir. Tablo incelendiğinde diğer liselerden mezun olan öğrencilerin sigara içme oranlarının daha yüksek olduğu belirlenmiştir (Tablo 4).

\begin{tabular}{|c|c|c|c|c|c|c|c|}
\hline & \multicolumn{6}{|c|}{ Sigara içiyor musunuz? } & \multirow[b]{2}{*}{ Önemlilik } \\
\hline $\begin{array}{l}\text { Eğitim } \\
\text { durumu }\end{array}$ & Evet & $\%$ & Hayır & $\%$ & Toplam & $\%$ & \\
\hline $\begin{array}{l}\text { Sağlık } \\
\text { Lisesi }\end{array}$ & 19 & 47.5 & 21 & 52.5 & 40 & 100 & \multirow{2}{*}{$\begin{array}{c}\text { Ki-kare: } .005 \\
\text { p: } .945\end{array}$} \\
\hline $\begin{array}{l}\text { Diğer } \\
\text { Liseler }\end{array}$ & 64 & 48.1 & 69 & 51.9 & 133 & 100 & \\
\hline Toplam & 83 & 48.0 & 90 & 52.0 & 173 & 100 & \\
\hline
\end{tabular}

Öğrencilerin sigara içme durumlarına göre başka alışkanlıklarının olup olmama durumları karşılaştırıldığında, gruplar arasında anlamlı farklılık meydana geldiğ (p:0.000), Tablo 5’te de görüldüğü gibi sigara içenlerin yüksek oranda alkol ve nargile alışkanlıklarının olduğu saptanmıştır.

Öğrencilerin sigara içme durumlarına göre anne ile babanın eğitim durumları ve öğrencilerin yaşam biçimleri karşılaştırıldığında gruplar arasında anlamlı farklılık meydana gelmediği ( $p>0.05)$ görülmektedir.

Öğrencilerin sigara içme durumlarına göre, anne sigara içme durumu karşılaştırıldığında gruplar arasında anlamlı farklılık meydana gelmediği ( $\mathrm{p}>0.05)$ görülmektedir.

Öğrencilerin sigara içme durumlarına göre, baba sigara içme durumu karşılaştırıldığında gruplar arasında anlamlı farklılık meydana geldiği (p:0.021), Tablo 6'da de görüldüğü gibi sigara içen öğrencilerin babalarının da sigara içme 
oranının yüksek olduğu tespit edilmiştir.

Öğrencilerin sigara içme durumlarına göre, yaşadıkları ortamda sigara içilme durumları karşılaştırıldığında gruplar arasında anlamlı farklılık meydana geldiği (p:0.002), Tablo 7’de de belirtildiği gibi sigara içen öğrencilerin yaşadıkları ortamlarda da sigara içilme oranlarının yüksek olduğu saptanmıştır.

\section{TARTIŞMA}

\begin{tabular}{|c|c|c|c|c|c|c|c|}
\hline \multirow[b]{2}{*}{ Başka alışkanlıklarınız var mı? } & \multicolumn{6}{|c|}{ Sigara içiyor musunuz? } & \multirow[b]{2}{*}{ Önemlilik } \\
\hline & Evet & $\%$ & Hayır & $\%$ & Toplam & $\%$ & \\
\hline Yok & 31 & 33.3 & 62 & 66.7 & 93 & 100 & \multirow{4}{*}{$\begin{array}{c}\text { Ki-kare: } 21.089 \\
\text { p: } .000\end{array}$} \\
\hline Alkol & 34 & 73.9 & 12 & 26.1 & 46 & 100 & \\
\hline Diğer bağımlıklar (uyuşturucu madde) & 5 & 45.5 & 6 & 54.5 & 11 & 100 & \\
\hline Nargile & 13 & 56.5 & 10 & 43.5 & 23 & 100 & \\
\hline Toplam & 83 & 48.0 & 90 & 52.0 & 173 & 100 & \\
\hline
\end{tabular}

Tablo 6. Sigara içme durumu ve baba sigara içme durumu

\begin{tabular}{|c|c|c|c|c|c|c|c|}
\hline \multirow[b]{2}{*}{ Baba sigara içiyor mu? } & \multicolumn{6}{|c|}{ Sigara içiyor musunuz? } & \multirow[b]{2}{*}{ Önemlilik } \\
\hline & Evet & $\%$ & Hayır & $\%$ & Toplam & $\%$ & \\
\hline Evet & 54 & 54.0 & 46 & 46.0 & 100 & 100 & \multirow{3}{*}{$\begin{array}{c}\text { Ki-kare: } 7.703 \\
\text { p: } .021\end{array}$} \\
\hline Hayır & 19 & 33.3 & 38 & 66.7 & 57 & 100 & \\
\hline Biraktı & 10 & 62.5 & 6 & 37.5 & 16 & 100 & \\
\hline Toplam & 83 & 48.0 & 90 & 52.0 & 173 & 100 & \\
\hline
\end{tabular}

Tablo 7. "Yaşadığınız ortamda sigara içiliyor mu?" sorusuna verilen yanıtların oranı

\begin{tabular}{|c|c|c|c|c|c|c|c|}
\hline \multirow[b]{2}{*}{ Yaşadığınız ortamda sigara içiliyor mu? } & \multicolumn{6}{|c|}{ Sigara içiyor musunuz? } & \multirow[b]{2}{*}{ Önemlilik } \\
\hline & Evet & $\%$ & Hayır & $\%$ & Toplam & $\%$ & \\
\hline Evet & 70 & 55.1 & 57 & 44.9 & 127 & 100 & \multirow{2}{*}{$\begin{array}{c}\text { Ki-kare: } 9.759 \\
\text { p: } .002\end{array}$} \\
\hline Hayır & 13 & 28.3 & 33 & 71.7 & 46 & 100 & \\
\hline Toplam & 83 & 48.0 & 90 & 52.0 & 173 & 100 & \\
\hline
\end{tabular}


Çalışmamızda, öğrencilerin "Sigara içiyor musunuz?" sorusuna verdikleri yanıtlar incelendiğinde \%48'inin sigara içtiği, \%45.65'inin içmediği ve \%6.35'inin ise “ $1 \mathrm{kez}$ deneyip sevmedikleri” görülmektedir. Sigara içen öğrencilerin \%33.73 oranında (n:28) kadın, \%66.26 oranında (n:55) erkek olduğu belirlenmiştir. Sigara içen öğrencilerin sigara içme sıklığı incelendiğinde \%26.5’inin "Ara sıra", \%73.5’inin ise "Her gün” sigara içtiği belirlenmiştir. Öğrencilerin sigaraya başlama yaşı olarak \%15.66 oranında (n:13) “17 yaş”, \%25.30 oranında (n:21) "18 yaş” olarak belirtilmiştir. Öğrencilerin günlük olarak tükettikleri sigara miktarları en yüksek oran ile 10 adet ve altı (\%56.6) olduğu tespit edilmiştir.

TUİK çalışmasına göre, ülkemizde 2016 yılında, 15-24 yaşında her gün sigara kullananların toplam oranı \%18.1 olarak saptanmıştır, kadınlarda bu oran \%7.8, erkeklerde \%28.2 olarak belirlenmiştir. 2010 yılında bu yaş grubunda sigara içme oranı \%16.4 iken, 2012 de \%18.5 olarak bildirilmiştir. ${ }^{11} \mathrm{Bu}$ yaş grubunda, yeni verilere bakıldı̆̆ında, 2010 yılına göre, sigara içme oranında artış olduğu belirlenmiştir. Bu rakamlarda artış olması, ülkemizde gençlerin sigara içme konusunda daha iyi bilinçlendirilmesinin gerekli olduğunu göstermektedir. Sigara ve diğer tütün ürünlerine bağımlılık konusunda alınan çeşitli önlemlere karşın, mücadelenin hala istenen düzeyde etkin olmadığ 1 görülmektedir. Yapılan çalışmalar sonucunda, Türkiye’de üniversite öğrencileri arasında sigara içme sıklığ $\% 18-48$, Sağlık Meslek Yüksekokulları özelinde ise \%37.5-55 olarak bildirilmiştir. ${ }^{12,17}$ Başka bir çalışmada da ülkemizde tıp fakültesi öğrencilerinin tütün bağımlılıklarını değerlendiren çalışmalarda, sigara içme oranının \%17-52.6 arasında olduğu, Avrupa ülkelerinde yapılan çalışmalarda da, tıp fakültesi öğrencilerinin sigara içme oranlarının \%11-61 arasında olduğu bildirilmiştir. ${ }^{18}$

Özcebe ve arkadaşları tarafından yapılan bir çalışmada, üniversite öğrencilerinde sigara içme oranını araştırmak için Adnan Menderes, Harran, Kırıkkale, Kocaeli, Mersin, Osmangazi, Ondokuz Mayıs, Yüzüncü Yıl üniversiteleri- nin 1. sınıf öğrencileri arasında 2004-2005 öğrenim yılında 3101 öğrenci ile yapılan bir araştırmada en az bir defa sigara kullanma oranı \%57.8 ve halen kullanma oranı ise $\% 22.5$ olarak saptanmıştır. ${ }^{19}$

İnandı ve arkadaşları tarafından yapılan, Türkiye'deki 12 tıp fakültesindeki 1217 öğrenciyle yapılan geniş katılımlı bir çalışmada öğrencinin tütün kullanım sıklığı araştırılmıştır. Öğrencilerin sigara içme sıklığı \%28.5 olarak bulunmuştur. Erkek öğrencilerde bu oran (\%29.3), kadın öğrencilerde (\%11.1) olarak bildirilmiştir. ${ }^{20}$

Atatürk Üniversitesi Narman Meslek Yüksekokulu’nda 407 öğrencide yapılan bir çalışmada, öğrencilerin \%30’unun sigara kullandığı, \%70’inin ise sigara kullanmadığ 1 belirtilmiștir. ${ }^{21}$

Bir sağlık meslek yüksekokulundaki hemşirelik-ebelik bölümündeki 504 öğrencinin halen sigara içme oranı \%12.3 olarak bildirilmiştir. ${ }^{22}$

Ege Üniversitesi Atatürk Sağlık Hizmetleri Meslek Yüksekokulu'ndaki 213 öğrencide yapılan çalışmada sigara içme oranı \%20.2 olduğu bildirilmiştir. ${ }^{23}$ Yine bir başka çalışmada, 308 hekim dışı sağlık personelinden oluşan [Hemşire, ebe, acil tıp teknikeri (ATT)] araştırmada, katılımcıların \%35.10 oranında sigara kullandığı bildirilmiştir. ${ }^{24}$

2017-2018 tarihlerinde 5 ülkede (Belarus, Litvanya, Polonya, Rusya, Slovakya) gerçekleştirilen ve 8800’ü tıp öğrencisi olan 14352 öğrencinin sigara içme oranının incelendiği bir çalışmada, sigara içme oranının \%66.1 olduğu ve tıp öğrencilerinin sigara içme oranı \%68.9 iken tıp dışı bölümlerde okuyan öğrenciler için bu oran \%61.8 olarak belirlenmiștir. ${ }^{25}$

Fransa, ABD, İspanya, Avusturalya ve İtalya'da hemşirelik okuyan (öğrenimi gören de denebilir) öğrencilerin sigara içme oranını araştıran bir çalışmada halen sigara içme prevalansı \%26.6 (22.9-30.4) olarak bildirilmiştir. ${ }^{26}$ 
10985 tıp fakültesi öğrencisinde yapılan bir çalışmada da sigara içme oranı \%18.9 olarak saptanmıștır. ${ }^{27}$

Kaptanoğlu ve arkadaşları tarafından 2937 tıp, diş hekimliği, eczacılık, hemşirelik-ebelik öğrencilerinde yapılan bir çalışmada öğrencilerin 472'sinin (\%19.4'ü) halen sigara içtiği belirlenmiştir. Aynı çalışmada 399 tıp, diş hekimliği, eczacılık, hemşirelik-ebelik öğretim üyelerinin 151'inin (\%37.84) halen sigara içtiği belirlenmiştir. ${ }^{28}$ Öğrencilerin sigara içme oranına göre, öğretim üyelerinin sigara içme oranlarının daha fazla olması, sigara bağımlılı̆̆ı konusundaki bilinçlendirmelerin yeterliliği hakkında şüphe oluşturmaktadir.

Ülkemizde sigara kullananların önemli bir kısmının sigaraya 20 yaşından önce başladığı görülmektedir. Sigara kullanmayı deneyen her iki gençten birisi sigara kullanmaya devam etmektedir. Gençler sigara kullanmaya başladıktan sonra bir kaç gün ile bir kaç hafta içinde yoksunluk semptomları gösterebilirler. ${ }^{29}$

Ülkemizdeki dokuz üniversitede Fen-Edebiyat, Eğitim ve Tıp Fakültelerinin birinci ve dördüncü sınıf öğrencilerini kapsayan bir çalışmada, 5221 öğrencide sigara bağımlılık oranı incelenmiştir. Bu araştırmaya katılan üniversite öğrencilerinden birinci sınıf öğrencilerinin ilk kez sigara

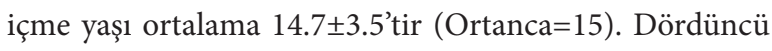
sinifta ise bu ortalama $15.5 \pm 4.2$ dir $($ Ortanca $=12) .{ }^{30}$

Mardin Artuklu Üniversitesi Sağlık Yüksekokulu'nda öğrenim gören 126 ebelik bölümü öğrencisinde yapılan bir

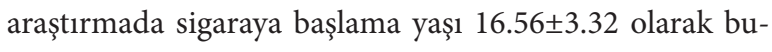
lunmuştur. ${ }^{31}$

Bizim çalışmamızdaki sonuçlar da literatürde bildirilen meslek yüksekokulundaki sigara içme oranları ile bağdaşmaktadır, bizim çalışmamızda sigara içme oranı oldukça yüksektir ve sigaraya başlama yaşı da en çok bildirilen yaş olan 18 ve 17 yaş grubudur. ${ }^{29,30,31} \mathrm{Bu}$ yaş grubundaki gençlerin bilinçlendirilmesinin önemi bu veriler ışığında daha iyi anlaşılmaktadır. Ülkemizde yapılan Küresel Gençlik Tütün Araştırması'na göre, halen sigara içenler arasında 18 yaşını doldurmamış olmasına rağmen, sigara satın alabilenler (Son 30 gün içinde sigara almaya çalışanlar arasında) \%73.3 oranında, yine bu yaş grubunda halen sigara içenler arasında, dal sigara satın alanlar (Son 30 gün içinde sigara satın alanlar arasında, en son sigara satın alındığında) \%29.4 oranında olarak bildirilmiştir. ${ }^{6}$ Bu sayılar, ülkemizde sigara satışında yaş sınırına yeterince uyulmadı̆̆ını göstermektedir, sigaraya rahat bir şekilde ulaşmak da gençlerin sigara bağımlılığını artırmaktadır. Sigara satışı yeterince denetlenirse, bu yaş grubunda bağımlılığın önlenme olasılığı artacaktır.

Çalışmamızda sigara içen ve içmeyen öğrenciler cinsiyetlerine göre değerlendirildiğinde, sigara içen öğrencilerin cinsiyetleri arasında anlamlı farklılık meydana geldiği, erkek öğrencilerin kız öğrencilerden daha yüksek oranda sigara içtikleri görülmektedir (p:0.003). Bu sonuçlar çoğu literatürdeki verilere uygunluk göstermektedir., ${ }^{7,20,31,32,33,34}$

Hemşirelik öğrencilerinde yapılan bir çalışmada, sigara içen öğrencilerin \%46.5'i sigaraya arkadaş etkileşimi ile başladıklarını, \%34.8’i okul ve ders stresi nedeniyle kullanmaya devam ettiklerini belirttiler. ${ }^{35}$ Bizim çalışmamızda ise sigara içen öğrencilerin, \%33.68'i (n:32) diğer nedenlerle (öylesine, bilinçli olarak, duyusal nedenler) sigaraya başladıklarını, \%48.2'si (n:40) zevk ve keyif verici olduğu için içmeye devam ettiklerini belirtmişlerdir.

227 Tip Fakültesi öğrencisinde yapılan bir çalışmada, katılımcılara sigaraya başlama nedenleri sorulduğunda, büyük çoğunluğu arkadaş çevresinin etkisinin olduğu (\%42) ve devam etmelerindeki en önemli nedenlerin ise sigaranın rahatlattığını düşünmeleri ve can sıkıntısına (\%39) iyi gelmesi olarak belirtmişlerdir. Sigaraya devam etmelerindeki diğer nedenler ise arkadaşlar arasında dikkat çekmesi, bazı şeyleri anlık unutturması ve sınav stresine iyi gelmesi olarak belirtilmiştir. ${ }^{36}$ Mardin Artuklu Üniversitesi Sağlık Yüksekokulu ebelik bölümünde öğrenim gören 126 öğren- 
ciyle yapılan bir çalışmada sigaraya başlama nedeni \%33.4 (n:5) ile aile sorunu, \%20 ile yalnızlık (n:3) ve \%13.3 ile (n:3) özenti olarak bulunmuştur. ${ }^{31}$

Çilingir ve arkadaşları tarafından, sağlık yüksekokulundaki hemşirelik ve ebelik bölümünde eğitim gören, 499 öğrencide sigara içen öğrencilerin \%62.5'inin arkadaş çevresi nedeni ile sigara kullanmaya başladıkları saptanmıştır. \%79.1'inin ise moral bozukluğu nedeniyle sigara içtiği saptanmıştır. ${ }^{37}$

Kılıç ve arkadaşları tarafından yapılan 365 öğrencideki çalışmada, sigaraya başlama nedenleri arasında en sık görüleni merak (\%28.4) ve arkadaşlardan etkilenme (\%21.6) olarak belirtilmiştir. ${ }^{32}$

Karabiber ve arkadaşları tarafından, tıp fakültesinde eğitim gören 304 öğrencide yapılan bir çalışmada, sigaraya başlamada etkili olan faktörlerde \%39 ile sosyal çevre öne çıkarken, bunu sırasıyla merak (\%34.2) ve tıp eğitimi ile ilgili sorunlar (\%20.1) izlemektedir. ${ }^{38}$

Tıp fakültesinde çalışan, 453 hastane personelinde, (doktor, hemşire, laborant, sağlık teknisyeni, idare görevlisi, temizlik görevlisi) sigaraya başlama nedenleri arasında merak ve özenti çalışanlar tarafından en sık bildirilen nedenlerdir. ${ }^{39}$

Çalışmamızda sigara başlama nedenleri açısından elde edilen veriler, literatürde bildirilen sonuçlarla uyumlu bulunmuştur. ${ }^{32,37,38,39}$

2016 yılındaki TUİK verilerine göre \%21.6 merak, \%29.1 arkadaş etkisi, \%29.7 özenti, sigara başlama nedenleridir. ${ }^{5}$ Gençler büyüdügüüü göstermek, birilerine özenti, kendini daha iyi hissetmek, anksiyetesini azaltma arzusu, büyüklerin otoritesine başkaldırı gibi nedenlerle sigara içmeye başlayabilirler. ${ }^{40}$ Toplum sağlığı ve bağımlılıkların önlenmesi açısından, çocukluk ve gençlik dönemi çok önemlidir. Gençlerin çok erken yaşlarda sigara ve tütün ürünleri karşıtlı̆̆ konusunda eğitilmeleri, stres nedenlerinin araştırılıp, bu nedenlere yönelik destek uygulanması, arkadaş etkisi ve stres gibi nedenlerle sigaraya başlamalarını ve devam etmelerini önleyecektir.

Çalışmamızda, sigara bağımlılığı olan öğrencilerin, sigaranın yanında başka alışkanlıklarının olup olmadığı sorusuna verdikleri yanıtlar incelendiğinde, \%55.42 oranında alkol kullandıkları, \%27.71 oranında ise nargile alışkanlıkları olduğu görülmektedir. Söylemez ve arkadaşları tarafindan 413 öğrencide yapılan bir çalışmada, alkol kullanan öğrencilerin \%78.6'sının sigara kullandığı, alkol kullanmayanların ise \%24.3'ünün sigara içtiği ve öğrencilerin alkol kullanımı ve sigara içme durumları arasındaki farkın istatistiksel olarak anlamlı bulunduğu bildirilmiştir. ${ }^{41}$

Kırklareli Üniversitesi’nde öğrenim gören, 902 öğrencide yapılan bir çalışmada, sigara içen gençlerde; içmeyenlere göre alkol alma ve madde deneme anlamlı düzeyde fazla bulunduğu belirtilmiştir. ${ }^{42}$

Mavili tarafından yapılan bir çalışmada, Pamukkale Üniversitesi Tip Fakültesi’nde öğrenim görmekte olan öğrencilerin 822'sinde sigara içen ve içmeyen öğrencilerin, diğer bağımlılık yapıcı madde kullanımları karşılaştırılmıştır. Araştırma grubunda, alkollü içecek kullananların \%38.2'sinin, nargile içenlerin \%33.6’sının, uyuşturucu madde kullananların ise \%65.9'unun sigara içtiği saptanmıştır. Alkollü içecek kullananlarda, nargile içenlerde, uyuşturucu madde kullananlarda, sigara içimi, içmeyen öğrencilere göre daha fazla bulunmuş ve bu farkın istatistiksel olarak anlamlı olduğu belirtilmiştir. ${ }^{43}$

İnönü Üniversitesi Malatya Sağlık Yüksekokulu’ndaki 504 öğrenci ile yapılan bir araştırmada, sigara içme oranı yüksek olan öğrencilerde, alkollü içecek tüketimini deneme oranının daha yüksek olduğu bildirilmiştir. ${ }^{22}$ Aktaş ve arkadaşları tarafından bir devlet üniversitesinin tıp ve güzel sanatlar fakültesinde okuyan toplam 156 ögrrencide yapılan çalışmada, sigara içen öğrencilerde nargile kullanım 
oranı \%76.3 iken, hiç sigara içmemiş olan öğrencilerde oran $\% 28.2$ bulunmuştur. ${ }^{44}$

Yaşar tarafından, 331 tıp fakültesinde yapılan uzmanlık tezinde, sigara içmeyen 263 kişiden 17 kişinin (\%6.5) nargile içtiği, sigara içen 53 öğrenciden 12 kişinin (\%22.6) nargile içtiği ve bu durumun istatistiksel açıdan anlamlı olduğu bildirilmiştir. ${ }^{45}$

Almanya, Norveç ve Macaristan'daki tıp fakültesi öğrencilerinde yapılan, çok merkezli kesitsel bir çalışmada nargile ve e-sigara kullanımının, sigara içenlerde, içmeyenlere göre daha fazla olduğu belirlenmiştir. ${ }^{46}$

Albisser tarafından, 204 gençte yapılan bir çalışmada, nargile içiminin genç yetişkinler arasında yaygın olduğu, sigara içimi ve esrar tüketimi ile güçlü bir şekilde ilişkili olduğu bildirilmiştir. ${ }^{47}$

$\mathrm{Bu}$ sonuçlar, gençlerin bağımlılık yapan ürünlerden, en kolay ulaşabilecekleri sigara ile birlikte nargile, alkol ve diğer bağımlılık yapan maddelere de bağımlı olma durumlarının arttığını göstermektedir. Bu nedenle tüm tütün ürünleri ve diğer maddelere bağımlılık konusunda çok genç yaşta eğitim verilmesi gerekmektedir.

Çalışmamızda, öğrencilerin sigara içme durumlarına göre baba sigara içme durumu karşılaştırıldığında gruplar arasında anlamlı farklılık meydana geldiği (p:0.021) belirlenmiştir. Veriler incelendiğinde sigara içen öğrencilerin babalarının da, sigara içme oranının daha yüksek olduğu görülmektedir. Öğrencilerin sigara içme durumlarına göre yaşadıkları ortamda sigara içilme durumları karşılaştırıldığında gruplar arasında anlamlı farklılık meydana geldiği (p:0.002) saptanmıştır. Sonuçlar incelendiğinde, sigara içen öğrencilerin yaşadıkları ortamlarda da sigara içilme oranlarının daha yüksek olduğu görülmektedir. Anne sigara içme durumu ise öğrencilerde sigara içme durumunu etkilememiştir.
Ceylan ve arkadaşları tarafından, 780 öğrenci üzerinde yapılan bir çalışma sonucunda, sigara kullanımının ana nedenleri olarak, aile ve arkadaş gruplarından etkilenme olarak bulunmuştur. Ayrıca, baba ve erkek kardeşlerin sigara içme alışkanlıkları arasında istatistiksel olarak anlamlı bir ilişki elde etmişlerdir. ${ }^{48}$

2017-2018 eğitim ve öğretim yılında, tıp fakültesinde okuyan 993 öğrenci ile yapılan bir çalışmada, annenin sigara içmesi, öğrencinin sigara içmesini etkilemez iken, babanın, kardeşlerin ve en yakın arkadaş çevresinin sigara içmesi etkili bulunmuştur. ${ }^{49}$

Tip fakültesinde eğitim gören 1. ve 6. sınıf düzeyinde 157 öğrencide yapılan bir çalışmada sigara içenlerin \%69.2'sinin (n:18) ailesinde sigara kullanan ebeveyn mevcutken, sigara içmeyenlerin \%36.6’sının (n:48) ailesinde sigara içen ebeveyn bulunduğu ve aralarında anlamlı istatistiksel fark olduğu belirtilmiştir (p:0.002)..$^{50}$

Atatürk Üniversitesi Narman Meslek Yüksekokulu’nda 407 öğrenci ile yapılan çalışmada, ailesinde sigara kullananların sigara kullanma olasılığı, ailesinde sigara kullanmayanların sigara kullanma olasılığına göre 3.003 kat daha fazla bulunmuştur. $^{21}$

İzmir Ege Üniversitesi Atatürk Sağlık Hizmetleri Meslek Yüksekokulu'nda 213 öğrencide yapılan bir araştırmada, öğrencilerin \%63'ünün evinde sigara içildiği belirlenmiştir. Sigara içen öğrencilerin (n:43) \%79.1'inin evinde sigara içiliyor iken, sigara içmeyen öğrencilerin (n:168) \%58.9'unun (n:99) evinde sigara içilmektedir. Evinde sigara içilme durumu ile öğrencinin kendisinin sigara içme durumu arasındaki ilişki istatistiksel olarak önemli olduğu belirtilmiştir (p:0.021). ${ }^{24}$

Bir üniversitenin sağlık bilimleri ve sosyal bilimlerinde öğrenim gören 602 öğrencide yapılan araştırmada, ailesinde sigara kullanımı olan öğrencilerin sigara içme oranının ailesinde sigara kullanımı olmayan öğrencilere göre daha 
yüksek olduğu belirlenmiştir (p.0.000)..$^{51}$

Eroğlu tarafından yapılan bir çalışmada, hastanede çalışan 164 personelde sigara içenlerin \%87'sinde anne, baba, eş ve kardeş olmak üzere, en az bir aile bireyinin sigara içtiği, sadece \%13'ünde ailede sigara içen bir birey olmadığı tespit edilmiştir. ${ }^{52}$

Düzce Üniversitesi Tıp Fakültesi’ndeki, 213 öğrencide yapılan bir çalışmada, annesi, babası ya da kardeşi sigara içenlerde, sigara içme oranının yüksek bulunduğu bildirilmiştir. ${ }^{16}$

Çilekar ve ark. tarafından, 516 tıp fakültesi öğrencisinde yapılan bir çalışmada, sigara içen öğrencilerin anne, baba, kardeş ve en yakın arkadaşında sigara içme oranları sorgulandığında 1.sırada arkadaşın, 2. sırada annenin, 3. sırada da \%19.3 oranında babanın sigara içmesinin etkili olduğu belirlenmiştir. ${ }^{18}$

Kutlu ve arkadaşları tarafından 993 tıp fakültesi öğrencisinde yapılan çalışmada, sigara içme durumu ile yakın arkadaş grubunun, babanın ve kardeşlerin sigara içmesi arasında anlamlı ilişki olduğu belirlendi. Annenin sigara içmesi öğrencinin sigara içmesini etkilemez iken babanın, kardeşlerin, en yakın arkadaş çevresinin sigara içmesi etkili bulundu. ${ }^{49}$

Bizim çalışmamızda ve incelediğimiz çalışma sonuçlarında da belirlendiği gibi, gençlerdeki sigara bağımlılığında, anne, baba, kardeş ve arkadaşın sigara içmesinin önemli faktör olduğu görülmektedir. Sigara bağımlılığı ve tütün ürünleri ile yapılan mücadelede gençlerin eğitilmesinin yanı sıra, ebeveynlerin eğitimi ve bilinç düzeylerinin artırılması gerekmektedir. Sigara ile mücadele stratejilerinde, birey ve yakın çevre de hedeflenmelidir.

Çalışmamızın tek okulda yapılmış olması, tüm öğrencilere ulaşılmamış olması kısıtlılık nedenleridir. Buna rağmen çalışmamız, sigara bağımlılı̆̆ı gibi önemli bir konuya dikkat çekmesi ve sigara bağımlılığı konusundaki eğitimin tekrar gözden geçirilmesi açısından uyarıcı özellik taşımaktadır. Toplumun genelinde etkili olabilmesi için, özellikle sağlık ve eğitim alanında çalışacak öğrencilerin, tütün ve tütün ürünlerinin kullanımından kaçınması ve bu ürünlere bağımlılığın engellenmesi konularında bilinçlendirilmesi önem arz etmektedir. Bu bilinçlendirmenin etkili olabilmesi için kulüp etkinlikleri, seçmeli ders müfredatları, sertifika programları ve kurslar gibi alternatif öğretim tekniklerinin uygulanması ve bu öğretim tekniklerinin alanında uzman kişiler tarafından planlanması gerektiğini düşünmekteyiz.

Bu çalışmaya ait etik kurul onayı Sağlık Bilimleri Üniversitesi Süreyyapaşa Göğüs Hastalıkları ve Göğüs Cerrahisi Girişimsel Olmayan Klinik Araştırmalar Etik Kurulu tarafından alınmıştır (116.2017.112 numaralı, 28.11.2019). 


\section{Kaynaklar}

1. Karlikaya C, Öztuna F, Solak ZA, Özkan M, Örsel O. Tütün Kontrolü. Toraks Dergisi 2006; 7(1): 51-64.

2. Bilir N. Sigarayı birakma yolları (sigaranın zararl etkilerinden korunma). Ankara: Klasmat Matbaactlik, 2008: 6-7.

3. World Health Organization, The WHO Framework Convention on Tobacco Control: an overview, Erişim, 21 Kasım 2020. http://www.who.int/fctc/WHO_FCTC_summary_January2015_EN.pdf

4. WHO Report on the Global Tobacco Epidemic, 2019. Geneva: World Health Organization; 2019. Licence: CC BY-NC-SA 3.0 IGO, Erişim, 21 Kasim 2020. https://www.who.int/teams/ health-promotion/tobacco-control/who-report-on-the-global-tobacco-epidemic-2019dpublication $=9789241516204$

5. TƯiK Türkiye Sağlk Araştırması 2016, Bireylerin Tütün Mamulü Kullanma Durumunun Cinsiyet ve Yaş Grubuna Göre Dă̆glımı tablosu. Erișim, 21 Kasım 2020. http://www.tuik. gov.tr/PreTablo.do?alt_id $=1095$

6. T.C. Sağ lk Bakanlğ̆ Halk Sağlğ̆ı Genel Müdürlü̆üu. Küresel Gençlik Tütün Araștırmast (KGTA-2017), 2017, Erișim 18 Mart 2020. https://hsgm.saglik.gov.tr/depo/birimler/tutun-mucadele-bagimlilik-db/duyurular/KGTA-2017_pdf.pdf

7. Atlam DHÇ, Yüncü Z. Üniversitesi Öğrencilerinde Sigara, Alkol, Madde Kullanım Bozukluğu ve Ailesel Madde Kullanımı Arasındaki İlişki. Klinik Psikiyatri 2017; 20: 161-170.

8. The Health Consequences of Smoking 50 Years of Progress. A report of the Surgeon General. U.S. Department of Health and Human Services, 2014.

9. Dağlı E. Ergenin Bağımlılık Süreci. Sürekli Tip Eğitimi Dergisi 2018; 27: 5-7.

10. Aslan D. Tütün Kontrolü Ị̇in “Tütünsüz” Úniversite Modelleri. Sürekli Tip Eğitimi Dergisi 2019; 28: 23-25.

11. T.C. Sağlık Bakanlı̆̆ı Sağllk Araștırmaları Genel Müdürlüğü, Sağllk İstatistikleri Yıllı̆̆l, 2016. Ankara. Erişim, 21 Kastm 2020. https://www.saglik.gov.tr/TR,30485/saglik-istatistikleri-yilligi-2016-yayinlanmistir.html

12. Hassoy H, Ergin I, Davas A, Durusoy R, Karababa AO. Sağllk Meslek Yüksekokulu Öğrencilerinde Sigara, Nargile, Sarma Tütün Kullanımını Etkileyen Faktörlerin Belirlenmesi ve Öğrencilerin Sigara, Nargile, Sarma Tütüne Başlama ve Sürdürme Konusundaki Görüşleri. Solunum Dergisi 2011; 13(2): 91-99.

13. Selçuk KT, Avcı D, Mercan Y. Üniversite Öğrencilerinde Sigara Bağımllı̆̆̆ı, Sigarayı Bırakmaya Yönelik İstek ve Öz-Etkililik. Clin Exp Health Sci 2018; 8: 36-43.

14. Karadağ G, Lafçı D. Hemșirelik Öğrencilerinin Sigara İçme Durumları ve Sağhlklı Yașam Biçimi Davranıșları. Erciyes Üniversitesi Sağlk Bilimleri Fakültesi Dergisi; 2015: 3(1).

15. Dağtekin G, Atay E, Ktlınç A ve ark. Tip Fakültesi Öğrencilerinde Cinsiyete Göre Sigara Tüketimi, Algilanan Stres ve Yaşam Kalitesi. Osmangazi Tip Dergisi 2020.

16. Mayda AS, Şahin G, Tosun T. Düzce Üniversitesi Tip Fakültesi Öğrencilerinde Sigara İçme Sıklğgı ve Etkileyen Faktörler. Düzce Tip Dergisi 2011; 13(1): 26-31.

17. Kutlu R, Vatansev C, Demirbaș N, Tașer S. Tip Fakültesi Ögrrencilerinde Tütün ve Tütün Ürünleri Kullanım Siklĭgı. TJFMPC, 2019; 13(2): 219-226.

18. Çilekar Ş, Dumanl A, Öz G, Günay E. Hastanemizde Tip Fakültesi Öğrencilerinin Tütün Kullanma Durumları. Bozok Tip Dergisi 2019; 9(4): 22-6.

19. Bilir N, Özcebe H. Türkiye’de tütün kontrolü uygulamaları. Turk J Public Health 2013; 11(2).

20. İnandı T, Yaman OK, Aydin N ve ark. Küresel Sağlık Meslekleri Öğrenci Anketi-Türkiye: ikinci el dumana maruz kalma ve tıp öğrencilerinin tütün karşıtı yasa hakkındaki görüşleri. Cent Eur J Halk Sağlığı 2013; 21 (3): 134-9.

21. Bedir S, Polat D, Dikmen AT. Atatürk Üniversitesi Narman Meslek Yüksekokulu Öğrencilerinin Sigara Kullanımın Etkileyen Faktörler. Atatürk Üniversitesi İktisadi ve İdari Bilimler Dergisi 2011; 25(2).

22. Koca B, Oğuzöncül AF. İnönü Üniversitesi Sağllk Yüksekokulu Öğrencilerinin Sigara, Alkol, Madde Kullanımı, Madde Kullanımına Etki Eden Etmenler ve Aileden Aldıkları Sosyal Desteğin Etkisi. Kocaeli Tip Dergisi 2015; 4(2): 4-13.

23. Kaylı DȘ, Yararbaș G. Ege Üniversitesi Meslek Yüksek Okulu Öğrencilerinin Sigara İçme Durumları. CBU-SBED, 2016; 2(5): 134-138.

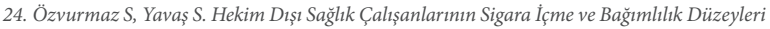
İle İlişkili Etmenler. Mersin Univ Sağhlk Bilim Derg 2018; 11(2): 157-166.

25. Brożek GM, Jankowski M, Lawson JA et al. The Prevalence of Cigarette and E-cigarette Smoking Among Students in Central and Eastern Europe-Results of the YUPESS Study. Int J Environ Res Public Health. 2019; 16(13): 2297.

26. Nilan K, McKeever TM, McNeill A, Raw M, Murray RL. Prevalence of tobacco use in healthcare workers: A systematic review and meta-analysis. PLoS One. 2019; 14(7).

27. Bourbon A, Boyer L, Auquier P et al. Anxiolytic consumption is associated with tobacco smoking and severe nicotine dependence. Results from the national French medical students (BOURBON) study. Progress in Neuro-Psychopharmacology and Biological Psychiatry.
2019; 94.

28. Kaptanoğlu AY, Polat G, Soyer M. Marmara Üniversitesi Öğrencilerinde ve Öğretim Üyelerinde Sigara Alışkanlı̆̆ ve Durağan Maliyet İlişkisi. Yükseköğretim ve Bilim Dergisi 2012; 2(2): 119-125.

29. Özcebe H. Gençler ve Sigara. Sağlık Bakanlı̆̆ı Yayın No: 731. Ankara: Klasmat Matbaacılık, 2008: 1-24.

30. Özcebe H, Doğan BG, İnal E, Haznedaroğlu D, Bertan M. Üniversite Öğrencilerinin Sigara İçme Davranışları ve İlișkili Sosyodemografik Özellikleri. Turk Toraks Derg 2014; 15: 42-8.

31. İnanç BB. Ebelik Bölümü Öğrencilerinde Sigara, Alkol, Madde Kullanımını Etkileyen Faktörler ve Aile Sosyal Desteği Ebelik Bölümü Öğrencilerinde Sigara, Alkol, Madde Kullanımını Etkileyen Faktörler ve Aile Sosyal Desteği. Euras J Fam Med 2015; 4(1): 29-35.

32. Kıllı̧ N, Ek HN. Adnan Menderes Üniversitesi Sağllk Yüksekokulu ve Sağllk Hizmetleri Meslek Yüksekokulu Öğrencilerinin Sigaraya Yönelik, Bilgi, Tutum ve Davranışları. Sağlik Bilimleri Dergisi 2006; 15(2): 85-90.

33. Yüksel S, Cücen Z. Üniversite Öğrencilerinin Sigara Bağımllığına İlișkin Tutumlarının Sigara İçme Sikliklarına Göre İncelenmesi. Turk Toraks Derg 2012; 13: 169-73.

34. Berberoğlu U, Tașpınar N, Öztaș D. Tip Eğitimi Başlangıcında Sigara Kullanımı ve Etkileyen Faktörler, Usak-2018. Ankara Med J, 2019; (4): 745-52.

35. Çapık C, Cingil D. Hemșirelik Öğrencilerinde Sigara Kullanımı, Nikotin Bağımlılık Düzeyi ve İliskili Etmenler. Kafkas J Med Sci 2013; 3(2): 55-61.

36. Aksoy F, Kaya K, Kizılkaya Z ve ark. Bir Tip Fakültesi 3. Sinıf Ögrrencilerinin Sigara İle İlgili Bilgi ve Görüs Durumları. SDÜ Tip Fakültesi Dergisi 2019; 26(1): 90-95.

37. Çilingir D, Hintistan S, Öztürk H. Sağllk Yüksekokulu Öğrencilerinin Sigara Kullanma Alşskanlıkları ve Etkileyen Faktörler. Gümüşhane Üniversitesi Sağlk Bilimleri Dergisi 2012; 1(2): 69-85.

38. Karabiber C, Azboy N, Altıner F ve ark. Tip Fakültesi Öğrencilerinin Tütün Kullanımı Hakkında Bilgi, Tutum ve Davranısları. Mustafa Kemal Üniv Tip Derg 2018; 9(33): 21-32.

39. Altın R, Kart L, Unalacak M, Dutkun Y, Örnek T. Tip Fakültesi Hastanesinde Çalışanlarda Sigara İçme Prevelanst ve Sigaraya Karşı Tutumlarının Değerlendirilmesi. Kocatepe Tip Dergisi 2004; 5(2): 63- 67 .

40. Karalezli A. Gençlik ve Sigara Bırakma Tedavileri. Güncel Göğüs Hastalıkları Serisi 2016; 4 (1): 128-135.

41. Söylemez F, Genç MF. The relationship of the smoking status of students in the school of he alth and vocational school of health services with the dependent personality trait. Medicine Science 2019; 8(4): 820-6.

42. Ulukoca N, Gökgöz Ş, Karakoç A. Kırklareli Üniversitesi Öğrencileri Arasında Sigara, Alkol ve Madde Kullanım Siklı̆̆ı. Firat Tip Dergisi 2013; 18(4): 230-234.

43. Mavili S. Pamukkale Üniversitesi Tip Fakültesi Öğrencilerinin Bağımlılık Yapıcı Madde Kullanım Durumları [tez]. Pamukkale Úniversitesi Tip Fakültesi Halk Sağhı̆̆ı Anabilim Dali; 2017.

44. Aktaş A, Hıdıroğlu S, Karakavuș M. Klinik Araștırma Üniversite Öğrencilerinin Nargile İcme Konusundaki Bilgi, Tutum ve Davranısları Firat Tip Dergisi 2018; 23 (2): 68-72.

45. Yaşar, Ç. Dicle Üniversitesi Tip Fakültesi öğrencilerinin 5727 sayll yeni Tütün Yasası Sonrası Sigara ve Nargile ile İlgili Bilgi, Tutum ve Davranıșlarındaki Değișiklikler [Yayımlanmamıș Uzmanlık Tezi]. Dicle Universitesi Tip Fakültesi, Göğüs Hastalıkları Anabilim Dalı; 2014

46. Balogh E, Faubl N, Riemenschneider $H$ et al. Cigarette, waterpipe and e-cigarette use among an international sample of medical students. Cross-sectional multicenter study in Germany and Hungary. BMC Public Health 2018; 18(1): 591.

47. Albisser S, Schmidlin J, Schindler C, Tamm M, Stolz D. Water pipe smoking and its association with cigarette and cannabis use in young adults in Switzerland. Respiration 2013, 86(3): 210-215

48. Ceylan E, Yanık M, Gencer M. "Harran Üniversitesỉne Kayıt Yaptıran Öğrencilerin Sigaraya Karşı Tutumlarını Etkileyen Faktörler”. Toraks Dergisi 2005; 6(2): 144-150.

49. Kutlu R, Vatansev C, Demirbaș N, Tașer S. The Frequency of Tobacco and Tobacco Product Use in Medical Faculty Students. Turkish Journal of Family Medicine and Primary Care 2019; 13(2): 219-226.

50. Bastürk M, Koç EM, Sözmen MK, Arslan M, Albas S. Tip Fakültesi Birinci ve Altıncı Stnıf Öğrencilerinin Sigara İçme Durumları, Anksiyete Düzeyleri ve 4207 Sayılı Kanun Hakkındaki Tutumları. Konuralp Tip Dergisi 2018; 10(3): 282-288.

51. Oğuz S, Çamcı G, Kazan M. Üniversite Öğrencilerinin Sigara Kullanım Sıklı̆ı ve Sigaranın Neden Olduğu Hastalıkları Bilme Durumu. Van Tip Dergisi 2018; 25(3): 332-337.

52. Eroğlu SA. İstanbul'da Genel Bir Devlet Hastanesinde Çalışanların Sigara İçme Durumu ve Etkileyen Faktörler. İstanbul Med J 2013; 14: 170-4. 